\title{
Effect of Mother's Monitoring and Psychological Control on Adolescents' Aggression: Mediating Role of Moral Disengagement
}

\author{
Hye yun Park ${ }^{1}$, Sae-Young Han ${ }^{2}$ \\ M. A., Department of Child Development \& Intervention, Ewha Womans University, Seoul, Korea ${ }^{1}$ \\ Professor, Department of Child Development \& Intervention, Ewha Womans University, Seoul, Korea ${ }^{2}$ \\ 어머니의 감독과 심리적 통제가 청소년의 공격성에 미치는 영향: \\ 도덕적 이탈의 매개적 역할 \\ 박혜윤 ${ }^{1}$ 한세영 ${ }^{2}$ \\ 이화여자대학교 아동학과 석사 ${ }^{1}$, 이화여자대학교 아동학과 교수 ${ }^{2}$
}

\begin{abstract}
Objectives: This study aimed to identify the direct effects of mothers' monitoring, psychological control, and indirect effects through moral disengagement on adolescents' aggression.

Methods: A total of 403 middle school students (147 males, 256 females) completed a self-report questionnaire, including measures of mothers' monitoring and psychological control and adolescents' moral disengagement and aggression. The collected data were analyzed using t-tests, correlation analysis, and structural equation modeling (SEM).

Results: Results revealed that the direct effects of mothers' monitoring and psychological control on adolescents' aggression and the indirect effects mediated by moral disengagement were significant.

Conclusion: This study underlines the importance of mothers' monitoring and psychological control and moral disengagement on adolescents' aggression. The study results defined that a cognitive distortion acted as an internal mechanism that produces aggression by discovering the significant mediating effect of moral disengagement accordingly indicated a need for a cognitive approach in the intervention programs of moral enhancement.
\end{abstract}

Keywords: monitoring, psychological control, moral disengagement, aggression

\section{Introduction}

청소년기는 급격한 발달적 변화가 이루어지는 시기인데, 이 시기에 청소년들이 갈등과 스트레스를 잘 해소하지 못하거나 발달과업을 잘 수행하지 못한다면 이는 공격성, 비행, 우울 등 의 문제행동으로 이어질 위험이 있다(Röonnlund \& Karlsson, 2006). 문제행동 중에서도 공격성과 폭력 문제는 사회적으로 문제가 되고 있으며, 최근 부산 여중생 폭행 사건과 인천 중학

Corresponding Author: Sae-Young Han, Professor, Department of Child Development \& Intervention, Ewha Womans University, 52, Ewhayeodaegil, Seodaemun-gu, Seoul, Korea

E-mail: evenhow@ewha.ac.kr
생 추락사 사건 등으로 청소년의 폭력과 또래 괴롭힘 문제에 대한 우려의 목소리는 더욱 커지고 있다. 2018년 1차 학교폭 력 실태조사에 따르면 학교폭력 피해 응답률은 전년도에 비 해서 증가하였으며, 폭력의 형태는 언어폭력, 집단따돌림, 스 토킹, 사이버 괴롭힘 순으로 나타났다(Ministry of Education, 2018). 청소년의 공격성은 학업적인 부분은 물론 비행, 범죄, 정신병리까지의 심각한 부적응적 결과로 확대될 위험이 있어 더욱 관심을 가져야 한다(Crick \& Grotpeter, 1995; Vaillancourt,

(C) The Korean Association of Child Studies

This is an Open Access article distributed under the terms of the Creative Commons Attribution Non-Commercial License (http:// creativecommons.org/licenses/by-nc/4.0) which permits unrestricted noncommercial use, distribution, and reproduction in any medium, provided the original work is properly cited. 
Brendgen, Boivin, \& Tremblay, 2003). 이로 인한 사회적 문제를 예방하기 위해서는 청소년기의 공격성을 예방하기 위한 적절 한 교육과 개입이 필요하며 이와 관련된 요인을 살펴볼 필요 성이 있다.

연구자들은 공격성에 가장 큰 영향을 미치는 요인을 가정과 부모의 양육행동으로 보았다(H. Y. Kim, 2010; D. Lee \& Yum, 2015). 본 연구는 부모의 양육행동 중 자녀의 발달에 긍정적인 영향을 미친다고 평가되는 감독과 부정적으로 평가되는 심리 적 통제로 나누어 공격성과의 상관을 살펴보고자 하였다.

감독은 자녀들이 어디에 있고, 누구와 함께 있으며, 어떤 활 동을 하는지 등에 관심을 가지는 양육행동으로 자녀에 대한 부모의 지식을 의미한다(Steinberg, Fletcher, \& Darling, 1995). 부모는 이 과정을 통해 자녀의 규칙을 설정하고 이에 따라 자 녀를 지도할 수 있다. 이전 연구자들은 부모가 자녀의 활동에 주의를 기울이고 감독자의 역할을 함으로써 자녀의 문제행 동을 예방할 수 있어야 한다고 하였다(Fuligni \& Eccles, 1993; $\mathrm{Oh}, 2010)$. 지나친 억압과 간섭의 부정적인 의미가 아닌 자녀 의 일상생활과 행동에 대한 부모의 긍정적 측면의 감독은 자 녀에 대한 관심과 보살핌의 지표로 볼 수 있으며, 부모의 감독 은 자녀로 하여금 부모가 자신에 대해 애정을 많이 가지고 있 다고 지각하게 하며(Harter, 1988), 자녀의 정서적 행복에도 도 움을 준다(Ceballo, Ramirez, Murray, \& Maltese, 2003). 이 과정 에서 부모와 청소년 자녀의 관계는 향상되고, 자녀는 낮은 공 격성과 문제행동을 보일 수 있다. 특히 청소년기는 또래로부 터 많은 영향을 받는 시기이며 또래동조성이 높아, 또래의 일 탈행동을 접한 청소년은 모델링을 통해 높은 수준의 공격성 과 비행을 보이게 된다(H. Lee \& Kim, 2011). 부모의 감독은 청소년 자녀와 긍정적 관계를 형성하게 하며 이 과정에서 서 로의 의사소통을 증진한다. 이에 따른 자녀에 대한 지식을 바 탕으로 부모는 청소년이 공격적인 행동을 보일 위험상황에서 나 더 나아가 일탈된 친구들과 어울리는 것을 방지하고, 문제 행동을 예방할 수 있으며 위험상황에 개입할 수 있다. 부모의 감독과 공격성에 관한 선행연구를 살펴보면, E. G. Lee와 Han (2016)의 청소년을 대상으로 한 연구에서는 감독과 공격성은 높은 부적 상관을 보였으며, 부모의 감독 수준이 높고, 양육행 동이 애정적일수록 자녀의 공격성이 감소하는 것으로 나타났 다. Yim, Kim과 Chung (2014)의 연구에서도 부모의 감독 수준 이 높을수록 청소년 자녀의 공격성은 낮아지는 것으로 나타났 다. 이외의 다수 선행연구에서 부모의 감독이 높을수록 자녀 의 공격성과 외현화 문제행동이 낮게 나타난다는 결과를 보 였다(Cha \& Kim, 2016; H. H. Kim, 2003; H. Y. Kim, 2010; S.
Kim, 2007; Ko, 2005; Pettit, Laird, Dodge, Bates, \& Criss, 2001).

심리적 통제는 자녀가 기대에 미치지 못할 때, 부모가 애 정을 철회하거나 자녀가 죄의식을 느끼게 하는 등의 심리적 인 수단을 이용하여 자녀의 개인적이고, 심리적인 영역에 지 나친 영향력을 행사하려고 하는 양육행동이다(Barber, 1996). 이전 연구들에서는 부모의 심리적 통제를 청소년의 공격성을 예측할 수 있는 중요한 변인 중 하나로 보았다(Jeon, 2007; H. H. Kim, 2003). 청소년기는 자율성 확립이 중요한 시기인데 심리적 통제는 이를 방해한다(Albrecht, Galambos, \& Jansson, 2007; Barber, 1996; Barber \& Harmon, 2002; Loukas, Paulos, \& Robinson, 2005; Steinberg, 1990). 부모로부터 심리적 통제를 받은 자녀는 정서적으로 안정감을 얻기 어려우며, 분노와 슬 픔 등의 부정적 감정을 느끼며 공격적인 행동을 보이기 쉽다 (Davies \& Cummings, 1994). 또한 자신이 통제받는다고 느끼 고, 이에 따라 좌절감과 수치심을 느낄 수 있으며, 부모의 기대 에 부응해야 한다는 부담감과 애정 철회의 불안을 느낄 수 있 다. 이런 부정적 정서를 경험한 청소년은 공격성과 외현화 문 제행동과 직접적인 영향이 있을 수 있다고 하였다(H. Y. Kim, 2010; E. Lee \& Lea, 2012). 부모의 심리적 통제와 공격성에 관 한 선행연구를 살펴보면, 최근에는 심리적 통제와 관계적 공 격성의 관계를 살펴보는 연구가 많이 이루어지고 있으며, 청 소년이 부모의 심리적 통제를 높게 지각할수록 관계적 공격 성을 더 많이 보였다(K. A. Kim \& Kweon, 2015; H. Lee \& Park, 2014). 이외에도 다수의 연구에서 부모의 심리적 통제가 높을 수록 자녀의 공격성과 외현화 문제행동이 많이 나타난다고 보고하였다(Chang, 2015; H. Kim, 2014; H. H. Kim, 2003; H. Y. Kim, 2010; H. S. Lee, 2016; Loukas et al., 2005; Min \& Han, 2012; Noh, 2012; Rathert, Fite, Gaertner, \& Vitulano, 2011).

이와 같이 선행연구들은 자녀에 대한 부모의 양육행동 중 긍정적으로 평가되는 감독과 부정적으로 평가되는 심리적 통 제가 청소년의 공격성에 영향을 미치는 중요한 요인임을 확인 하였다. 본 연구는 긍정적 양육행동인 감독과 부정적 양육행 동인 심리적 통제라는 두 변인이 청소년의 공격성에 미치는 영향을 한 모델 안에서 살펴봄으로써 부모의 양육행동 중 긍 정적 측면의 활성화와 부정적 측면의 비활성화의 의미가 청소 년의 도덕적 이탈과 공격성에 대해 상대적으로 어떠한 효과를 갖는지를 살펴보고, 이를 통해 부모의 양육을 세분화하여 그 중요성을 다시 한번 강조하고자 하였다. 나아가 부모의 감독 과 심리적 통제가 청소년의 공격성에 영향을 미치는 이 과정 에서 작동하는 청소년의 내적, 인지적 메커니즘을 살펴보고자 하였다. 부모의 감독과 심리적 통제가 불러올 청소년의 내면 
의 변화가 공격성이라는 행동으로 표현될 것이라는 예측하에, 다양한 내적 인지적 메커니즘 중 도덕성 발달과 접점에 있는 도덕적 이탈이 작동할 것으로 예상하였다.

사회인지 이론을 기반으로 한 도덕적 이탈은 자신의 유 해한 행동이나 비도덕적 행동을 인지적 왜곡을 통해 자 기 합리화하여 행동을 정당화하는 것을 의미한다(Bandura,

Barbaranelli, Caprara, \& Pastorelli, 1996). 사회인지 이론에 따 르면 청소년의 도덕적 이탈은 공격성과 같은 반사회적인 행 동을 모델링 할 수 있는 경험이나 또는 그것을 받아들이는데 필요한 태도나 신념에 노출되는 경험이 필요하다고 하였다 (Bandura et al., 1996). 부모의 감독은 청소년 자녀와 긍정적인 관계를 형성하게 하며, 청소년이 위험하고 유해한 행동을 저 지를 상황에 개입할 가능성을 낮출 뿐 아니라 경험하거나 관 찰하는 도덕적 이슈에 대해 건강한 해석과 판단을 하도록 할 가능성을 높이기 때문에 도덕적 이탈로 이어질 가능성이 낮으 며, 따라서 또래관계 등에서도 공격성과 같은 반사회적 행동 이 낮게 나타날 수 있다. 반면에 부모로부터 심리적 통제를 받 은 청소년은 부모와 부정적인 상호작용이 이루어지며 좌절, 수치심, 불안과 같은 부정적 감정을 경험한다. 청소년은 그 과 정에서 심리적 통제와 같은 부모의 양육행동을 모델링하고 받 아들일 가능성이 높아지며, 이는 본인이 경험하는 도덕적 갈 등적 이슈에 대해 왜곡된 해석과 판단을 하게 하는 도덕적 이 탈과 같은 인지적으로 편향된 심리적 기제를 형성하게 하여 이를 통해 또래관계 등에서도 공격성과 같은 반사회적인 행동 으로 이어질 가능성이 높아지게 된다.

선행연구들은 이러한 도덕적 이탈과 공격성의 관계를 설명 한 바 있는데, Bandura (1991)는 타인에 대해 공격적인 행동을 보인 사람은 자신의 행동과 결과를 정당화하고 부정적인 감정 에서 벗어나기 위해 도덕적 이탈을 보인다고 하였고, Guerra 와 Slaby (1990)는 도덕적 이탈과 같은 인지적 왜곡이 반사회 적 행동 중에서도 특히 공격성에 영향을 미친다고 하였다.

H. Kim (2014)의 연구에서는 외적 귀인 성향이 높을수록 공격성이 높다고 하였다. 이는 공격성을 보이는 청소년이 본 인의 유해한 행동에 대한 책임을 회피하고, 행동의 원인을 피 해 학생이나 주변 환경으로 돌리는 모습이 더 많이 나타날 가능성이 있다. 또한, 공격성을 보이는 청소년은 그렇지 않 은 청소년에 비해 도덕적 정서와 책임감을 낮게 지각하였다 (Menesini, Sanchez, Fonzi, Ortega, Costabile, \& Feudo, 2003). 즉 대부분의 선행연구들이 도덕적 이탈과 공격성이 정적 상관이 있음을 밝혔으며(S. Seo, 2018; Shin \& Kim, 2014), 도덕적 이탈 수준이 높을수록 공격성이 높게 나타난다는 결과를 보인 것이
다(Kokkinos, Voulgaridou, Mandrali, \& Parousidou, 2016; H. S. Lee, 2016; Yoo, 2018).

부모의 양육행동은 자녀의 도덕성 발달에 큰 영향을 미치 며(Malti \& Krettenauer, 2013), 어머니의 양육행동은 아동기는 물론, 초기 청소년의 도덕성 발달에도 직접적인 영향을 미치 는 것으로 나타났다(J. S. Lee, 2016). 부모의 감독을 통해 자녀 는 부모의 애정을 느끼게 되며(Harter, 1988), 보호받는다는 느 낌과 함께 정서적 행복과 안정감에도 도움을 받는다(Ceballo et al., 2003). 부모의 감독은 부모와 자녀가 긍정적 관계를 형 성하고 원활한 의사소통을 하며 일상에서 많은 부분을 공유하 도록 도와준다. 청소년이 공격적인 행동을 저지를 위험상황 에 처했을 때, 부모는 감독을 통해 적절하게 조정하고 개입할 수 있으며, 그 과정에서 자녀는 자연스럽게 부모의 도덕적 규 준을 내면화하며 도덕성을 발달시킬 수 있다. 이에 따라 청소 년이 도덕적 이탈로 이어질 가능성은 낮아질 수 있다. 감독이 도덕적 이탈에 미치는 영향에 관한 선행연구들은 어머니의 감 독 및 애정적 양육이 도덕적 이탈에 부적 영향을 미쳤음을 밝 혔다(Pelton, Gound, Forehand, \& Brody, 2004; Yun, 2018). 또한, 양육자가 부족한 모니터링을 포함하는 부정적 양육행동을 많 이 보일수록 자녀는 높은 도덕적 이탈을 보인다고 보고 한 바 있다(Campaert, Nocentini, \& Menesini, 2018).

다음으로 심리적 통제 또한 도덕적 이탈과 밀접한 관련이 있는 것으로 보고되었는데, 부모의 심리적 통제는 자녀의 외 적 귀인 성향과 관련이 있음을 보고하였다(H. Kim, 2014). 부 모의 심리적 통제를 받은 자녀는 죄책감, 불안 등의 부정적인 정서를 느끼며 이런 상황을 회피하기 위해 변명을 하게 된다. 이때 자신의 유해한 행동의 이유를 외적 요인으로 돌리며 자 신의 잘못을 인정하려 하지 않고, 책임을 덜기 위한 인지적 왜 곡이 일어남으로써 도덕적 이탈이 나타날 수 있다. 선행연구 에서는 심리적 통제가 청소년 자녀의 도덕적 이탈에 미치는 영향이 유의하게 나타났는데, 부모의 심리적 통제가 높을수 록 청소년의 도덕적 이탈은 높은 수준을 보였다(J. M. Kim \& Kim, 2013; Sohn \& Han, 2019).

이러한 선행연구에 근거하여 어머니의 감독, 심리적 통제 가 청소년의 도덕적 이탈을 매개로 하여 공격성에 영향을 미 치는 경로를 논리적으로 추론해볼 수 있다. 비슷한 맥락의 연 구를 살펴보면, Yun (2018)의 연구는 청소년 자녀가 어머니의 양육행동을 애정, 합리적으로 인식할수록 도덕적 이탈 수준이 낮게 나타났고, 이는 청소년 비행에도 영향을 미쳤다. 심리적 통제와 관련하여 J. M. Kim과 Kim (2013)의 연구에서는 청소 년이 부모의 심리적 통제를 지각하는 정도가 높을수록 도덕적 
이탈 수준이 높았고, 그 결과 높은 가해행동을 보인다고 하였 다. 그러나 긍정적 양육행동인 감독과 부정적 양육행동인 심 리적 통제를 도덕적 이탈과 함께 살펴본 연구는 많지 않다. 청 소년기의 발달적 특징상, 어머니로부터 독립적인 판단과 사 고, 행동영역을 구축함과 동시에 한편으로는 생활에서 어머니 의 보호를 필요로 하는 상반된 측면이 공존한다. 어머니는 청 소년의 사고와 행동, 사회적 관계에 대해 적정 정도의 정보를 가지고 통제해야 함과 동시에 청소년기 심리의 독립적 지향을 이해하고 지지해 주어야 하는데, 이와 같은 청소년기 자녀에 대한 적합하고 바람직한 감독과 통제의 수준을 유지하는 것은 양육자에게도 쉬운 과제가 아니다. 본 연구에서는 청소년기 의 인지적 도덕발달이 형성되고 왜곡되는 과정에서 양육자의 긍정적 감독과 부정적 통제가 어느 정도의 영향을 미치는지 를 함께 살펴보아, 청소년기 자녀를 양육하는 양육자가 자녀 에 대한 감독과 통제의 기준을 탐색하는 과정에 도움이 될 기 초자료를 제공할 필요가 있다고 판단하였다. 따라서 양육자의 적절한 통제의 한 지표인 감독과 부적절한 통제의 한 지표인 심리적 통제가 청소년기의 도덕적 인지적 왜곡인 도덕적 이탈 에 어떠한 영향을 미치는지를 동시에 파악하여 청소년의 인지 적 도덕발달에서 손상을 방지하기 위해서는 양육자가 청소년 기 자녀에 대해 어떠한 수준의 통제를 행해야 하는지를 밝히 고자 하였다. 또한 이를 통해 공격성이라는 행동문제에는 어 떠한 영향을 미치게 되는지를 함께 살펴보고자 하였다.

본 연구는 어머니의 감독과 심리적 통제가 청소년의 공격 성에 미치는 직접적인 영향과 도덕적 이탈을 통해 미치는 간 접적인 영향을 살펴보는 것을 목적으로 하였다. 이를 통해 외 적 요인으로 볼 수 있는 어머니의 양육행동인 감독과 심리적 통제가 청소년의 공격성에 미치는 영향뿐 아니라 청소년의 내 적, 인지적 요인인 도덕적 이탈을 매개로 하여 공격성으로 이 어지는 경로를 살펴볼 수 있다. 또한 도덕적 이탈과 같은 인지 적 왜곡을 일으키는 요인으로 어머니의 감독과 심리적 통제로 세분화하여 살펴보며 어머니의 양육행동의 중요성을 강조하 였다. 따라서 이 결과는 관련 요인들의 관계를 이해하고 도덕 적 이탈의 수준을 낮춰, 사회문제로 이어질 수 있는 청소년의 공격성을 예방하기 위한 방안을 모색하는 데 도움이 되는 기 초자료로 활용될 수 있을 것이다.

\section{연구문제 1}

어머니의 감독과 심리적 통제가 청소년의 공격성에 직접적으 로 영향을 미치는가?

\section{연구문제 2}

어머니의 감독과 심리적 통제가 청소년의 도덕적 이탈을 통 해 공격성에 간접적으로 영향을 미치는가?

\section{Methods}

\section{연구대상}

본 연구의 조사는 2018년 12월 중 서울특별시와 전라북도에 위 치한 2 곳의 중학교에 재학 중인 403 명의 남녀 청소년을 대상으 로 하였다. 본 연구대상을 중학생으로 선정한 이유는 청소년기 는 새로운 도덕 개념이 형성되고 도덕성 발달에 있어 매우 중요 한 시기이며(Cho, 2012), 폭력적인 행동과 공격성이 두드러지게 나타나는 시기이기 때문이다(Blitstein, Murray, Lytle, Birnbaum, \& Perry, 2005). 연구 대상자의 인구통계학적 특성을 살펴보면, 성별 구성은 남학생 147 명(36.5\%), 여학생 256(63.5\%)이었다. 학년 구성은 1학년 186명(46.2\%), 2학년 117명(29.0\%), 3학년 100 명(24.8\%)이었다. 연령은 만 13세 183명(45.4\%), 만 14세 120 명(29.8\%), 만 15세 100명(24.8\%)으로 평균 연령은 13.79세로 나 타났다. 부모의 교육 수준을 살펴보면 어머니의 경우 4 년제 대 학 졸업이 138 명(34.2\%)으로 가장 많았으며, 고등학교 졸업이 110 명 $(27.3 \%)$ 으로 그다음으로 많은 것으로 나타났다. 아버지의 경우도 4년제 대학 졸업이 151 명(37.5\%)으로 가장 많았으며, 다 음으로는 고등학교 졸업이 90 명(22.3\%)이었다.

\section{연구도구}

본 연구의 조사도구는 어머니의 감독과 심리적 통제, 청소년 의 도덕적 이탈 및 공격성을 측정하기 위한 질문지로 구성되 었으며, 청소년의 보고로 이루어졌다.

\section{감독}

어머니의 감독은 Stattin과 Kerr (2000)이 개발한 부모감독 척 도(Parental Monitoring Scale)를 Park (2001)이 번안한 것을 사용 하여 측정하였다. 총 9문항으로 구성되어있다.

각 문항은 전혀 그렇지 않다(1점), 대체로 그렇지 않다(2 점), 대체로 그렇다(3점), 매우 그렇다(4점)로 이루어져 있으며 4점 Likert식 척도이다. 각 문항을 합산한 점수가 높을수록 청 소년이 지각한 어머니의 감독 수준이 높음을 의미한다. 본 연 
구에서의 내적 합치도(Cronbach's $\alpha$ )는 .83이었다. 본 연구에 서 어머니의 감독은 단일 차원으로 구성되어 있어 구조방정 식 모형 분석을 실시하기 위하여 각각의 문항을 부분적으로 합산하여 측정변수로 설정하는 항목 묶음(item parceling) 방법 을 사용하였다(Little, Cunningham, Shahar, \& Widaman, 2002). Little, Rhemtulla, Gibson과 Schoemann (2013)의 제안에 따라 세 개의 문항 묶음을 사용하였으며, 그 과정에서 요인부하량 이 0.4 미만인 감독 9 번 문항을 제외하였다.

\section{심리적 통제}

어머니의 심리적 통제는 Barber (1996)가 개발한 심리적 통제 척도(Psychological Control Scale-Youth Self Report [PCS-YSR]) 를 Jeon (2007)이 번안한 척도를 사용하였다. 척도는 자기표현 제한(3문항), 감정 불인정(3문항), 비난(3문항), 죄책감 유발(2 문항), 애정 철회(3문항), 불안정한 감정 기복(2문항)의 6 개의 하위요인으로 구성되어 있다.

각 문항은 전혀 그렇지 않다(1점), 대체로 그렇지 않다(2 점), 대체로 그렇다(3점), 매우 그렇다(4점)로 4점 Likert식 척 도로 이루어져 있다. 각 문항을 합산한 점수가 높을수록 청소 년이 지각한 어머니의 심리적 통제 수준이 높음을 의미한다. 본 연구의 내적 합치도(Cronbach's $\alpha$ )는 .90으로 나타났다. 확 인적 요인분석(Confirmatory Factor Analysis [CFA]) 결과, 심리 적 통제의 하위요인 중 비난의 요인부하량이 .40 이하로 산출 되어 이를 제외하였다.

\section{도덕적 이탈}

청소년의 도덕적 이탈은 Bandura (1996) 등이 개발한 도덕 적 이탈 기제 척도(Mechanism of Moral Disengagement Scale [MMDS])를 M. J. Seo와 Kim (2006)이 번안하고 수정한 척도 를 사용하여 측정하였다. 본 척도는 도덕적 정당화(4문항), 완 곡한 명명(2문항), 유리한 비교(4문항), 책임 전가(4문항), 책임 분산(4문항), 결과 왜곡(4문항), 비인간화(4문항), 비난의 귀인 (3문항)의 8 개의 하위요인으로 구성되어 있다.

각 문항은 전혀 그렇지 않다(1점), 대체로 그렇지 않다(2 점), 대체로 그렇다(3점), 매우 그렇다(4점)로 이루어져 있으 며 4점 Likert식 척도이다. 8개의 각 하위요인의 점수가 높을수 록 청소년의 도덕적 이탈 수준이 높다는 것을 의미한다. 각 하 위요인 별 내적 합치도(Cronbach's $\alpha$ )를 살펴보면, 도덕적 정 당화는 .70 , 완곡한 명명은 .59 , 유리한 비교는 .84 , 책임 전가
는 . 68 , 책임 분산은 .92 , 결과 왜곡은 . 73 , 비인간화는 . 81 , 비난 의 귀인은 .58 로 나타났다. 완곡한 명명과 비난의 귀인의 신뢰 도는 선행연구에서도 낮게 나타나 이를 제외 후 분석한 것으 로 보고된 바 있다(Sohn \& Han, 2019). 이에 따라 본 연구에서 도 이를 제외하고 도덕적 이탈을 분석하고자 한다. 또한 확인 적 요인분석(CFA) 결과, 도덕적 이탈의 하위요인 중 책임분산 의 요인부하량이 .40 이하로 산출되어 이를 제외하였다.

\section{공격성}

청소년의 공격성은 Marsee, Kimonis와 Frick (2004)이 제작한 자기보고형 또래갈등척도(Peer Conflict Scale [PCS])를 Han (2008)이 번안한 척도를 사용하여 측정하였다. 본 척도는 반응 적 외현적 공격성( 10 문항), 주도적 외현적 공격성( 10 문항), 반 응적 관계적 공격성(10문항), 주도적 관계적 공격성(10문항) 의 4 개의 하위요인으로 이루어져 있다.

각 문항은 전혀 그렇지 않다(1점), 대체로 그렇지 않다(2 점), 대체로 그렇다(3점), 매우 그렇다(4점)로 이루어져 있으며 4점 Likert식 척도이다. 4 개의 각 하위요인의 점수가 높을수록 청소년의 공격성 정도가 높음을 의미한다. 각 하위요인 별 내 적 합치도(Cronbach's $\alpha$ )를 살펴보면, 반응적 외현적 공격성은 .86 , 주도적 외현적 공격성은 .83 , 반응적 관계적 공격성은 .82 , 주도적 관계적 공격성은 .83으로 나타났다.

\section{연구절차}

본 연구의 조사는 2018년 12월 중 서울특별시와 전라북도에 위치한 2곳의 각 중학교에 협조를 요청하여 동의를 얻은 후, 12월 중 각 학교에 설문지를 배부하여 자료를 수집하였다. 설 문을 실시하기 위해 담임교사에게 조사 내용과 조사 방법에 대해 설명하였고 담임교사에 의해 설문지 조사가 실시되었다. 설문지의 응답시간은 약 20 분 정도 소요되었다. 배부된 430 부 중 414 부가 회수되어 약 $96 \%$ 의 회수율을 보였다. 그중 무응답 설문지를 포함한 11 부를 제외하고 최종 분석에 총 403 부를 사 용하였다. 정규성이 확보되는지 살펴보기 위해 왜도 및 첨도 의 절대값을 살펴본 결과, 각각 3 과 10 미만으로 나타나 정규 성 기준을 충족하였다(G. Kim, 2010).

\section{자료분석}

본 연구에서 수집된 자료들은 SPSS 22.0 프로그램(IBM Co., 
Armonk, NY)과 AMOS 21.0 프로그램(IBM Co., Armonk, NY) 을 사용하여 다음과 같은 방법을 통해 분석하였다. 연구대상 의 사회인구학적 배경 및 특성을 살펴보기 위해서 빈도와 백 분율을 산출하였으며, 조사도구의 문항 간 내적 합치도를 살 펴보기 위해 Cronbach's $\alpha$ 값을 산출하였다. 또한 각 변인 간의 상관관계를 알아보기 위해 Pearson의 적률상관계수를 산출하 였다. 그 후 어머니의 감독과 심리적 통제가 도덕적 이탈을 통 해 청소년의 공격성에 미치는 영향을 탐색하기 위해서 구조방 정식 모형(Structural Equation Modeling [SEM])을 분석하였다. 측정변인이 각각의 잠재변인을 잘 구성하고 있는지를 확인하 기 위해 확인적 요인분석(CFA)을 실시한 결과, 심리적 통제 의 하위요인 중 비난과 도덕적 이탈의 하위요인 중 책임분산 의 요인부하량이 .40 이하로 산출되어 이를 제외한 후 분석하 였다. 다음으로 측정모형이 포함된 구조모형의 적합도를 산출 하여 검증하였다. 또한 간접효과의 유의성을 평가하기 위하여 부트스트래핑(bootstrapping) 방법을 실시하였다.

\section{Results}

\section{측정 변인들 간 상관관계}

어머니의 감독과 심리적 통제 그리고 청소년의 도덕적 이탈 및 공격성 간의 상관관계를 살펴보기 위해 Pearson의 적률상 관계수를 산출한 결과는 Table 1과 같다. 구체적으로 관계를 살펴보면 첫째, 어머니의 감독과 심리적 통제 및 청소년의 공 격성 간의 상관관계와 관련하여 감독의 하위요인들은 청소년 의 공격성의 모든 하위요인에서 유의한 부적 상관을 보였다 $(r$ = -.32 .-20, $p$ <.001). 즉 어머니의 감독을 높게 지각할수록 청 소년의 모든 공격성의 하위 유형인 반응적 외현적 공격성, 주 도적 외현적 공격성, 반응적 관계적 공격성, 주도적 관계적 공 격성은 낮게 나타났다. 심리적 통제의 하위요인과 청소년 공 격성의 하위요인에서는 심리적 통제의 감정 불인정과 죄책감 유발은 주도적 관계적 공격성과 유의미한 상관이 나타나지 않 았다. 이를 제외한 심리적 통제와 청소년 공격성의 하위요인 들은 정적 상관을 보였다 $(r=.11 \sim .36, p<.05 \sim .001)$.

둘째, 도덕적 이탈과 공격성 간의 상관관계를 살펴보면, 도 덕적 이탈의 모든 하위요인들은 공격성의 모든 하위요인들과 정적 상관 $(r=.20 \sim .50, p<.001)$ 을 보였다. 즉 도덕적 이탈의 하위요인인 도덕적 정당화, 유리한 비교, 책임 전가, 결과 왜 곡, 비인간화가 높을수록 청소년 공격성의 하위요인인 반응적
외현적 공격성, 주도적 외현적 공격성, 반응적 관계적 공격성, 주도적 관계적 공격성은 높았다.

마지막으로, 어머니의 감독 및 심리적 통제와 도덕적 이 탈 간의 상관관계와 관련하여, 감독의 하위요인 중 감독3과 도덕적 이탈의 하위요인인 도덕적 정당화, 책임전가는 유의 미한 상관이 나타나지 않았다. 그 이외 감독의 하위요인들과 도덕적 이탈의 하위요인들은 유의한 부적 상관을 보였다 $(r=$ -.19 -.11,p<.05 .001). 심리적 통제와 도덕적 이탈의 상관관 계는 심리적 통제의 하위요인인 감정 불인정과 죄책감 유발은 모든 도덕적 이탈의 하위요인들과 유의미한 상관이 나타나지 않았으며, 이를 제외한 심리적 통제와 도덕적 이탈의 하위요 인들은 정적 상관을 보였다 $(r=13 \sim .21, p<.01 \sim .001)$.

\section{측정모형 분석}

어머니의 감독, 심리적 통제와 청소년의 도덕적 이탈 및 공격 성을 측정하는 측정변인이 각각의 잠재변인을 잘 구성하고 있 는지 살펴보기 위해 확인적 요인분석(CFA)을 실시하였다. 확 인적 요인분석의 모수추정은 최대우도법(maximum likelihood estimation)을 사용하였다. 측정모형의 적합도는 $\chi^{2}$ 와 $\chi^{2} / d f$, Normed Fit Index (NFI), Tucker-Lewis Index (TLI), Comparative Fit Index (CFI), Root Mean Square Error of Approximation (RMSEA), Standardized Root Mean Square Residual (SRMR)을 통한 적합도 지수로 평가하였다. 적합도 평가의 기준은 $\chi^{2}$ 값이 통 계적으로 유의하지 않고, $\chi^{2} / d f$ 값이 3 보다 작을 때 적합하다고 판단할 수 있으나(Kline, 2015), $\chi^{2}$ 값은 표본의 수에 크게 영향 을 받기 때문에 다른 적합도 지수를 같이 고려하여 모형의 적 합도를 판단하여야 한다. 일반적으로 NFI, TLI, CFI값이 .90 이상이면 높은 적합도로 해석하고, RMSEA는 .05 이하인 경 우 적합도가 적절하며 .08 이하인 경우 양호한 것으로 판단한 다(Hong, 2000). 또한 SRMR은 .08 이하인 경우 양호하다고 판단한다(Hu \& Bentler, 1999). 본 측정모형의 적합도 지수를 살펴보면, $\chi^{2}=296.366(d f=113, p<.001), \chi^{2} / d f=2.623$, NFI $=.910, \mathrm{TLI}=.930, \mathrm{CFI}=.942, \mathrm{RMSEA}=.064(90 \% \mathrm{CI}[.055$, $.072]), \mathrm{SRMR}=.052$ 로 적절한 수준의 적합도를 보였다(Table 2). 또한 최종모형의 요인부하량과 관련하여 모든 잠재변인에 서 측정변인으로의 표준화회귀계수( $\beta$ )가 .417 .918로 나타났 고, 회귀계수가 통계적으로 유의한지 판단할 수 있는 측정변 수들의 Critical Ratio (CR) 값은 $\alpha=.001$ 수준으로 모두 유의하 였다. 따라서 측정변인이 잠재변인을 적절하게 설명하고 있는 것으로 나타났다(Figure 1). 


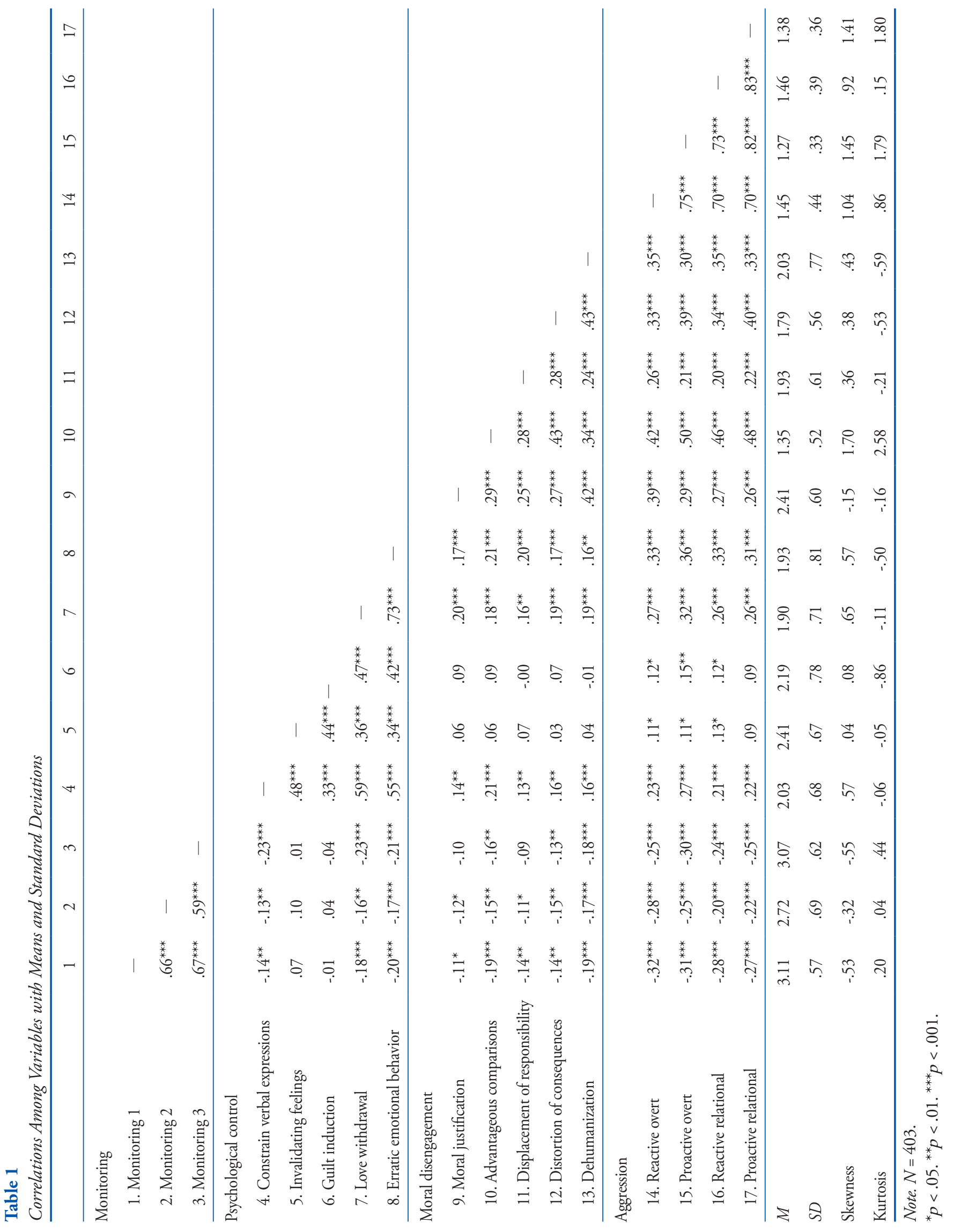


Table 2

Testing the Fit of the Measurement Model

\begin{tabular}{ccccccc}
\hline$\chi^{2}$ & & & & & & RMSEA \\
(LO90 HI90) & SRMR \\
\hline $296.366^{* * *}$ & 113 & 2.623 & .910 & .930 & .942 & .064 \\
\end{tabular}

Note. $N=403$.

*** $p<.001$.

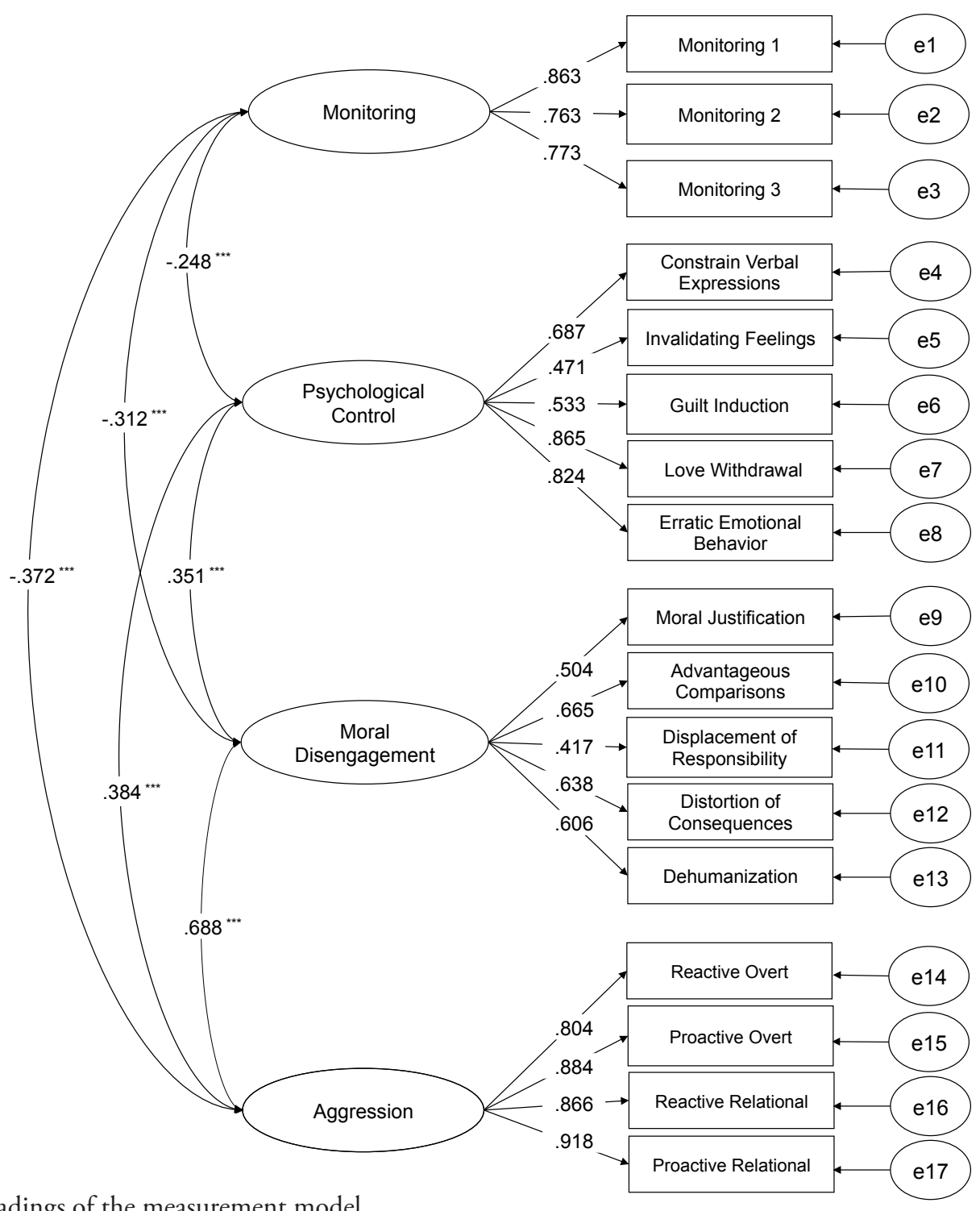

Figure 1. Factor loadings of the measurement model.

${ }^{* * *} p<.001$.

\section{구조모형 분석}

구조모형의 적합도 지수는 $\chi^{2}=296.366(d f=113, p<.001), \chi^{2}$ I $d f=2.623, \mathrm{NFI}=.910, \mathrm{TLI}=.930, \mathrm{CFI}=.942, \mathrm{RMSEA}=.064$ $(90 \% \mathrm{CI}[.055, .072]), \mathrm{SRMR}=.052$ 로 적합도 기준을 충족하
였다. 어머니의 감독과 심리적 통제가 청소년의 도덕적 이탈 을 통해 공격성에 미치는 경로는 다음과 같다(Table 3). 첫째, 어머니의 감독이 청소년의 공격성에 미치는 직접적인 경로 는 유의하였다 $(\beta=-.153, p<.05)$. 또한 어머니의 심리적 통제 가 청소년의 공격성에 미치는 직접적인 영향도 유의하였다 $(\beta$ 
Table 3

Path Coefficient of Structural Model

\begin{tabular}{lcccc}
\hline & $B$ & $\beta$ & $S E$ & \\
\hline Monitoring $\rightarrow$ Aggression & -.110 & -.153 & .036 & $-3.066^{*}$ \\
Psychological control $\rightarrow$ Aggression & .073 & .138 & .027 & $2.735^{*}$ \\
Moral disengagement $\rightarrow$ Aggression & .447 & .592 & .056 & $7.936^{* *}$ \\
Monitoring $\rightarrow$ Moral disengagement & -.228 & -.239 & .062 & $-3.680^{* *}$ \\
Psychological control $\rightarrow$ Moral disengagement & .205 & .292 & .046 & $4.435^{*}$ \\
\hline
\end{tabular}

Note. $N=403$.

${ }^{*} p<.05 .{ }^{* *} p<.01$.

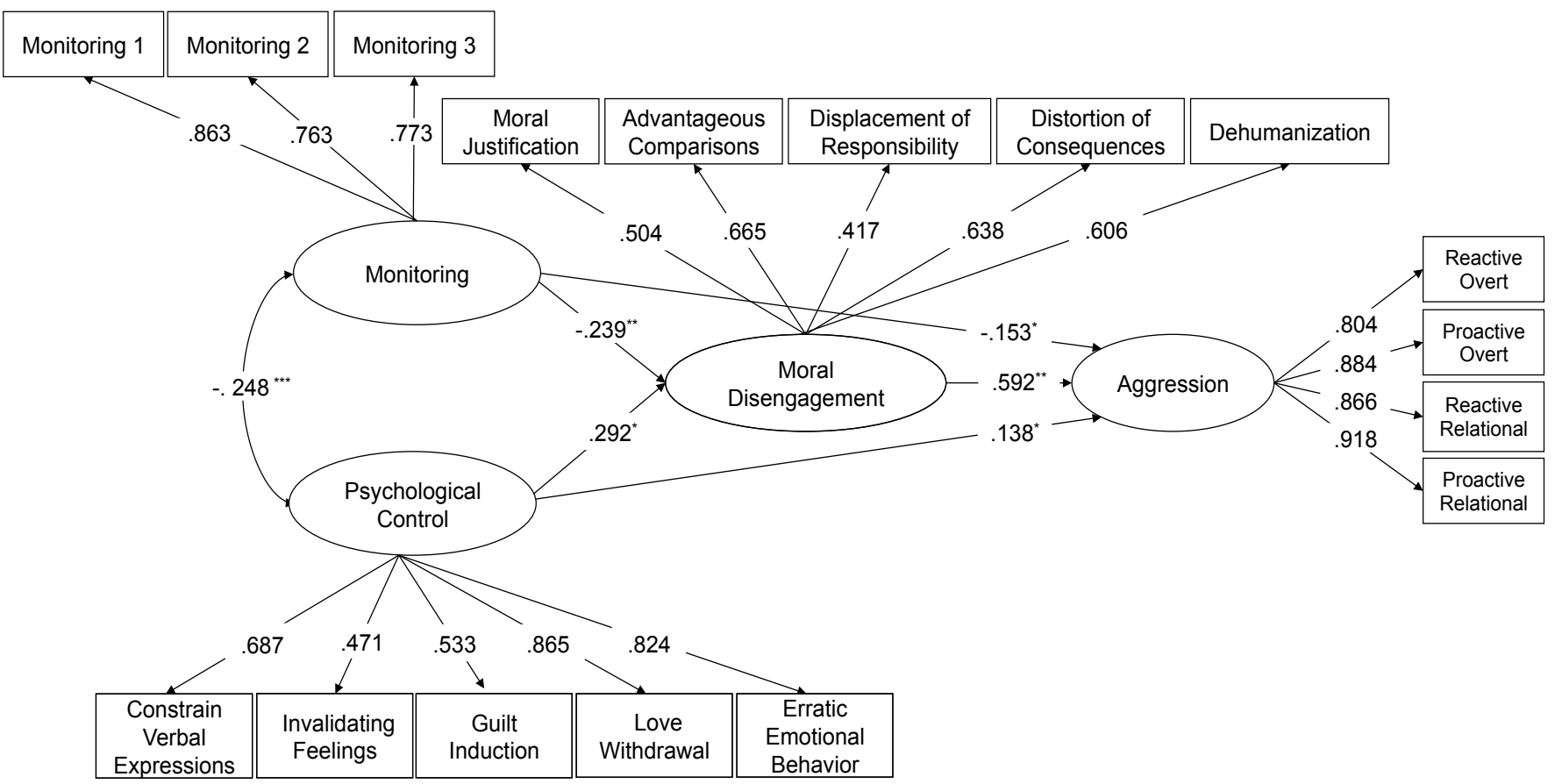

Figure 2. Direct and indirect paths from mothers' monitoring and psychological control to adolescents' aggression through moral disengagement.

${ }^{*} p<.05 .{ }^{* *} p<.01 .{ }^{* * *} p<.001$.

$=.138, p<.05)$. 둘째, 어머니의 감독과 심리적 통제가 도덕적 이탈을 통해 청소년의 공격성에 영향을 미치는 간접 경로와 관련하여, 먼저 어머니의 감독이 도덕적 이탈에 영향을 미치 는 경로는 부적으로 유의하였으며 $(\beta=-.239, p<.01)$, 어머니 의 심리적 통제가 도덕적 이탈에 영향을 미치는 경로는 정적 으로 유의하였다 $(\beta=.292, \mathrm{p}<.05)$. 또한 도덕적 이탈에서 청 소년 공격성으로의 경로는 정적으로 유의하였다 $(\beta=.592, p<$ .01). 즉, 어머니의 감독과 심리적 통제는 청소년의 도덕적 이 탈을 통해 공격성에 간접적인 영향을 미쳤다. 청소년이 어머 니의 감독을 높게 지각할수록 도덕적 이탈 수준은 낮았고, 심 리적 통제를 높게 지각할수록 도덕적 이탈 수준이 높았다. 그
리고 도덕적 이탈 수준이 높을수록 청소년의 공격성은 높게 나타났다. 종합하면, 자녀가 지각한 어머니의 감독과 심리적 통제가 도덕적 이탈을 통해 청소년의 공격성에 영향을 미치는 간접 경로가 유의하게 나타났다(Figure 2).

한편, 잠재변인 간의 구조적 관계를 자세히 살펴보기 위해 어머니의 감독과 심리적 통제가 청소년의 공격성에 미치는 직 접효과와 도덕적 이탈을 통한 간접효과와 총효과를 살펴보았 다(Table 4). 그 결과를 살펴보면, 청소년의 공격성에 가장 큰 영향을 미치는 변인은 도덕적 이탈 $(\beta=.592, p<.01)$ 로 나타 났고, 다음으로 심리적 통제 $(\beta=.310, p<.01)$, 감독 $(\beta=-.295$, $p<.05)$ 순으로 나타났다. 또한 어머니의 감독과 심리적 통제 
Table 4

Direct, Indirect, and Total Effects in the Structural Equation Model

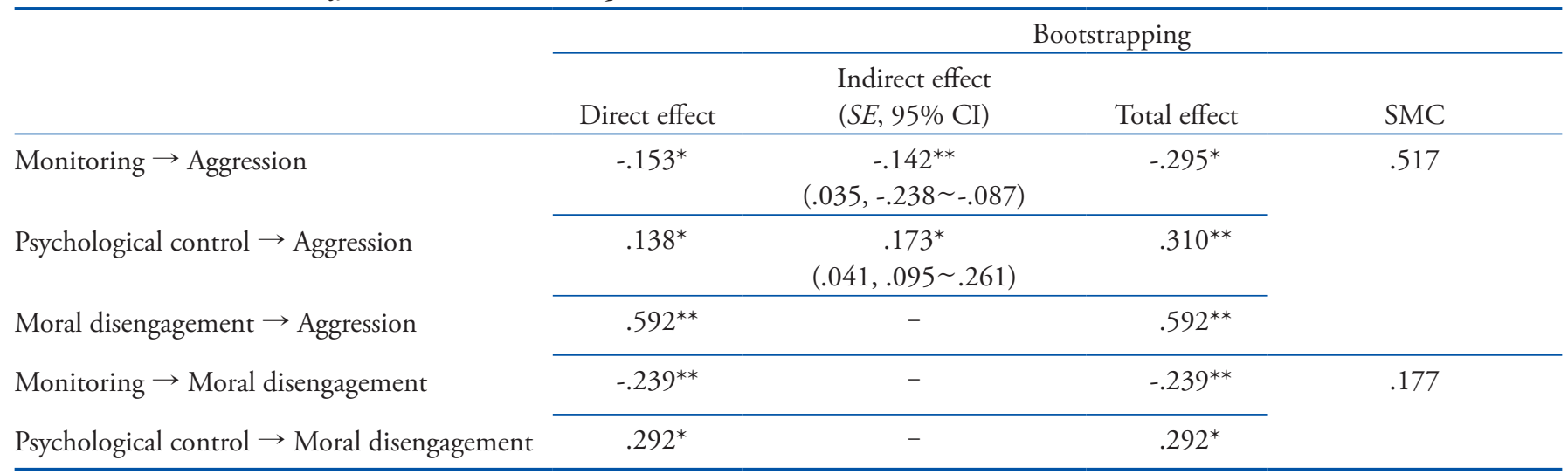

Note. $N=403$.

${ }^{*} p<.05 .{ }^{* *} p<.01$.

가 도덕적 이탈에 미치는 영향을 살펴본 결과, 어머니의 심리 적 통제 $(\beta=.292, p<.05)$, 어머니의 감독 $(\beta=-.239, p<.01)$ 순 으로 나타났다. 부트스트래핑(bootstrapping) 방법을 이용하여 간접효과의 유의성을 살펴본 결과, 신뢰구간 $95 \%$ 를 기준으 로 간접효과를 검증하였을 때, 신뢰구간 범위가 감독의 경우 -.238 -.087, 심리적 통제의 경우 .095 .261로 모두 0을 포함 하지 않아 도덕적 이탈의 매개효과가 통계적으로 유의한 것으 로 나타났다. 자세히 살펴보면, 어머니의 감독이 도덕적 이탈 을 통해 청소년의 공격성에 미치는 간접효과는 유의하였으며 $(\beta=-.142, p<.01)$, 심리적 통제가 도덕적 이탈을 통해 청소년 의 공격성에 미치는 간접효과도 유의하였다 $(\beta=.173, p<.05)$. 외생변수가 내생변수의 변량을 설명하는 정도를 의미하는 다 중상관자승(Squared Multiple Correlations [SMC])을 살펴본 결 과, 어머니의 감독 및 심리적 통제는 도덕적 이탈과 함께 청소 년의 공격성을 $51.7 \%$ 를 설명하였으며, 어머니의 감독과 심리 적 통제는 도덕적 이탈의 $17.7 \%$ 를 설명하였다.

\section{Discussion}

본 연구는 어머니의 감독 및 심리적 통제가 청소년의 공격성 에 미치는 직접적인 영향과 도덕적 이탈을 통한 간접적인 영 향을 살펴보는 것을 목적으로 하였다. 우선 어머니의 감독이 청소년의 공격성에 미치는 직접적인 영향을 살펴본 결과, 어 머니 감독은 청소년의 공격성에 직접적인 영향을 미치는 것으 로 나타났다. 즉, 어머니의 감독을 높게 지각한 청소년의 공격 성은 낮게 나타났다. 이러한 연구 결과는 어머니의 감독이 청
소년의 공격성과 외현화 문제에 유의한 영향을 미친다는 다 수의 선행연구를 지지하는 결과이다(Cha \& Kim, 2016; H. H. Kim, 2003; Ko, 2005; E. G. Lee \& Han, 2016; Pettit et al., 2001; Yim et al., 2014). 어머니의 긍정적 양육행동인 감독을 높게 지 각한 청소년은 어머니가 자신에게 애정과 관심을 가지고 있다 고 생각하고 어머니와 긍정적인 관계를 형성하여 긍정적 정서 와 안정감을 느낄 수 있다. 또한 감독을 통해 자녀의 일상생활 에 대한 정보와 지식을 가지고 있는 어머니는 자녀가 공격적 인 행동을 보이면 이를 제지할 수 있고, 더 나아가 일탈된 또래 들과 어울리거나 비도덕적이고 부적절한 위험 상황에 처할 위 기에서 빠른 개입이 가능하다. 이는 청소년들이 공격성과 같 은 문제행동으로 이어지는 것을 예방할 수 있기 때문에 낮은 공격성을 보이는 것으로 해석된다.

긍정적 양육행동으로 평가되는 감독과 대조적으로 부정적 인 양육행동으로 평가되는 어머니의 심리적 통제 또한 청소년 의 공격성에 직접적인 영향을 미치는 것으로 나타났다. 즉, 어 머니의 심리적 통제를 높게 지각할수록 청소년의 공격성은 높 게 나타났다. 이러한 연구 결과는 어머니의 심리적 통제가 청 소년의 공격성 및 외현화 문제에 영향을 미친다는 다수의 선 행연구를 지지하는 결과이다(Chang, 2015; H. Kim, 2014; H. H. Kim, 2003; K. A. Kim \& Kweon, 2015; H. Lee \& Park, 2014; H. S. Lee, 2016; Loukas et al., 2005). 어머니의 심리적 통제는 청소년의 가장 중요한 발달 과업인 자율성과 정체성 확립을 방해한다. 청소년은 어머니로부터 심리적으로 통제받고 있다 고 느끼며 자신의 의지대로 행동할 수 없을 때, 불만과 좌절감, 수치심 등의 부정적인 감정을 경험할 수 있다. 또한 심리적 통 제는 자녀로 하여금 자신이 부모의 기준을 충족하지 못했다는 
죄책감과 애정 철회의 불안을 느끼게 한다. 이러한 어머니의 심리적 통제로 인한 청소년의 부정적 감정은 우울, 불안, 분노 등의 정서적 문제를 야기할 수 있으며, 부정적인 감정과 정서 적 문제를 잘 해결하지 못한 청소년들은 외현적으로 공격성이 발현될 수 있다.

다음으로 어머니의 감독과 심리적 통제가 도덕적 이탈을 통해 청소년의 공격성에 미치는 간접적인 영향을 살펴본 결 과, 이는 유의한 것으로 나타났다. 어머니 감독 수준이 높을수 록 청소년의 도덕적 이탈 수준은 낮게 나타났으며, 이는 낮은 공격성으로 이어졌다. 또한 청소년이 어머니의 심리적 통제를 높게 지각할수록 도덕적 이탈은 높게 나타났고, 이는 높은 공 격성으로 이어졌다. 이를 경로별로 자세히 논의하면 다음과 같다.

첫째, 어머니의 감독과 심리적 통제가 도덕적 이탈에 미치 는 영향은 모두 유의하게 나타났다. 청소년이 어머니의 감독 을 높게 지각할수록 도덕적 이탈은 낮게 나타났으며, 이는 부 족한 모니터링을 포함하는 부정적 양육행동이 높을수록 자녀 의 도덕적 이탈이 높게 나타난다는 연구결과(Campaert et al., 2018)와 감독, 애정, 합리적인 긍정적 양육행동이 도덕적 이 탈에 부적 영향을 미친다는 연구결과를 지지한다(Pelton et al., 2004; Yun, 2018). 어머니의 감독은 자녀로 하여금 자신이 보호 받고 있다고 느끼게 해주어 안정적인 부모와 자녀 관계를 형 성하는 데 도움을 준다. 이를 바탕으로 어머니와 자녀 간 의사 소통이 증진되며 어머니는 자녀의 생활에 대한 지식을 얻고, 자연스럽게 일상생활을 공유하게 된다. 이 과정에서 청소년은 어머니로부터 사회적으로 수용되는 도덕적 기준과 태도를 습 득하고, 도덕성을 향상시키며 낮은 도덕적 이탈 수준을 보일 수 있다.

또한 청소년이 어머니의 심리적 통제를 높게 지각할수록 도덕적 이탈 수준은 높게 나타났다. 이러한 결과는 부모의 심 리적 통제가 청소년의 도덕적 이탈에 유의한 영향을 미친 것 으로 보고된 J. M. Kim과 Kim (2013)의 선행연구와 일치하는 것으로 볼 수 있으며, 어머니의 심리적 통제가 청소년 여학생 의 도덕적 이탈에 정적으로 영향을 미친 Sohn과 Han (2019)의 연구와도 일치한다. 애정적이지 못한 양육을 받은 청소년은 어머니와 안정적인 관계 형성과 상호작용이 적절히 이루어지 지 못해 도덕성을 획득하기 어려우며, 이는 높은 도덕적 이탈 과 연관될 수 있다. 또한 부모의 심리적 통제를 경험한 자녀는 애정 철회의 불안, 죄책감을 느끼며 이런 부정적인 감정을 회 피하기 위해 자신의 행동에 대해 책임감을 느끼고 잘못을 인 정하기보다 외적 귀인 성향을 보이며 자신의 행동에 대해 변
명하고 원인을 환경적 요인으로 돌리는 도덕적 이탈을 보일 수 있다. 때문에 부모는 양육과정에서 감독과 같은 긍정적 양 육행동을 바탕으로 자녀에게 관심을 가지고 적절한 감독과 규 율을 적용하여, 청소년 자녀가 사회적으로 허용되는 올바른 도덕적 규준을 내재화할 수 있도록 도와주어야 할 것이며, 자 녀에게 심리적으로 부정적 영향을 미치는 심리적 통제와 같은 양육행동은 지양하여야 할 것이다.

둘째, 도덕적 이탈은 공격성에 영향을 미치는 것으로 나타 났다. 즉 도덕적 이탈 수준이 높을수록 청소년의 공격성이 증 가함을 나타낸다. 이는 도덕적 이탈이 청소년의 공격성에 정 적으로 영향을 미쳤다는 선행연구들과 일치한다(Kokkinos et al., 2016; H. S. Lee, 2016; Yoo, 2018). 도덕적 이탈이 높은 청소 년은 공격성과 같은 유해한 행동을 보인 후, 자신의 잘못을 인 정하지 않고 책임을 외부로 돌리며 스스로에 대한 부정적 감 정을 회피하기 위한 인지적 왜곡 과정을 보인다. 이러한 기제 를 가지고 있는 사람은 낮은 책임감과 죄책감을 경험하며 더 욱 높은 공격성을 보이는 것으로 해석할 수 있다.

마지막으로, 어머니의 감독과 심리적 통제는 청소년의 도 덕적 이탈을 통해 공격성에 간접적으로 영향을 미쳤다. 이 변 인들 간의 관계를 다루는 연구는 많지 않지만, 감독과 같이 긍 정적 양육행동으로 평가받는 애정, 합리적 양육행동이 도덕적 이탈을 통해 청소년의 비행에 간접적인 영향을 미쳤음을 보여 준 Yun (2018)의 연구결과는 이와 비슷한 맥락으로 볼 수 있다. 그리고 심리적 통제와 도덕적 이탈이 공격성에 미치는 영향과 관련된 연구는 비슷한 맥락에서 부모의 심리적 통제가 도덕적 이탈에 영향을 미쳐 가해행동에 영향을 미친다고 보고한 J. M. $\operatorname{Kim}$ 과 Kim (2013)의 연구와 일치하는 결과를 보였다. 본 연구 는 어머니의 감독과 심리적 통제가 청소년의 공격성에 미치는 영향에서 도덕적 이탈의 매개적 역할을 확인하였다. 이는 어 머니의 긍정적 양육행동인 감독을 통해 청소년의 도덕적 이탈 을 감소시킬 수 있으며, 심리적 통제는 청소년의 도덕적 이탈 을 높일 수 있는 위험요소임을 확인하였다. 이와 같이 본 연구 는 어머니의 양육행동의 중요성을 시사한다.

본 연구는 어머니의 감독과 심리적 통제가 청소년의 공격 성에 미치는 직접적인 영향을 살펴보았다. 이는 자녀에 대한 관심을 기반으로 한 애정적 양육의 중요성을 다시 한번 강조 하는 결과이며, 이런 연구를 바탕으로 청소년의 공격성 감소 또는 예방을 위한 부모교육 등에 기초자료로 활용될 수 있을 것이다. 본 연구는 또한 어머니의 감독과 심리적 통제가 청소 년의 공격성에 미치는 영향에서 도덕적 이탈의 간접적인 영향 을 살펴보았다. 즉 어머니의 양육행동이라는 외적 요인이 청 
소년의 공격성에 영향을 미치는 과정에서 청소년의 내적, 인 지적 요인인 도덕적 이탈이 작용한다는 것을 발견하고, 양육 의 영향이 공격성이라는 외현화되는 문제행동으로 표출되기 까지 작동하는 내적 메커니즘을 중요하게 생각하였다는 것에 의미가 있다. 그 결과, 어머니의 양육행동이 청소년의 도덕적 이탈에 영향을 미쳐, 공격적인 행동으로 발현될 수 있음을 확 인하였다. 하지만 이 과정에서 청소년이 외적 요인을 어떻게 흡수하고 이를 내면화하는지에 따라 도덕적 이탈의 정도와 공 격성에 대한 태도는 다르게 나타날 수 있다. 청소년은 가정에 서는 물론 다양한 사회적 환경을 통해 정보를 습득하며 많은 영향을 받는데, 청소년이 접하는 부모, 또래, 교사와 같은 다양 한 외적 요인들로부터 주어지는 영향을 인지적으로 어떻게 수 용하고 또는 왜곡하는지, 이를 통해 도덕적 규준을 작동시킬 수 있음을 시사하는 결과인 것이다. 즉 공격성의 감소를 위해 서는 외부 영향요인을 파악하여 환경의 변화를 도모할 뿐 아 니라 외적 요인의 영향을 인지적으로 해석하고 작동하는 메커 니즘인 도덕적 이탈의 수준을 감소시키거나 예방할 수 있는 방안도 함께 모색해야 함을 알려주는 것이다.

이에 따라 청소년 공격성 감소를 위해서 가정은 물론 학교 에서의 예방적 개입과 교육의 중요성에 대해서도 관심을 가져 야 함을 시사한다. 이러한 본 연구의 결과는 위험요인에 노출 되어 있는 청소년을 위한 상담적 개입과 학교폭력 예방 또는 감소를 위한 도덕성 향상 프로그램 등의 기초자료가 될 수 있 을 것이다.

종합하면, 본 연구의 결과는 어머니의 감독과 심리적 통제 가 청소년의 공격성에 미치는 직접적인 영향과 도덕적 이탈 을 통해 미치는 간접적 영향이 모두 유의하였다. 이러한 결과 에서 본 연구는 어머니의 긍정적인 양육행동인 감독과 부정적 양육행동인 심리적 통제가 각각 반대 방향으로 청소년의 도덕 적 이탈과 공격성에 영향을 미친다는 상대적 역할을 확인하였 으며, 또한 각 영향의 크기 또한 유사한 수준으로 나타났음을 확인하였다. 이는 자녀의 공격성과 같은 문제행동과 관련하 여 어머니의 양육행동의 중요성을 다시 한번 강조하는 결과이 며, 특히 감독과 같은 긍정적 양육의 측면을 실행하는 것과 심 리적 통제와 같은 부정적 양육의 측면을 자제하는 것이 청소 년의 도덕적 이탈을 예방하고 공격성을 감소시키는데 유사한 수준의 무게를 갖는다는 사실을 발견한 결과이기도 하다. 또 한 그 과정에서 청소년의 내적, 인지적 요인인 도덕적 이탈의 간접적 영향을 밝혔다는데 본 연구의 의의가 있다. 이러한 결 과는 추후 청소년 따돌림, 폭력과 같은 공격적인 문제행동에 대한 예방 및 개입과정에 있어 외적 요인인 부모의 양육행동
이 도덕성과 같은 개인의 내적 요인에 영향을 미친다는 사실 을 반영할 필요가 있음을 시사한다. 그러므로 부모는 양육 과 정에서 도덕적 인식을 형성하는 청소년의 내적, 인지적 메커 니즘에 대해 관심을 가지고 청소년들이 올바른 도덕적 기준과 태도를 형성할 수 있도록 자녀의 일상생활에 주의를 기울이며 적절한 개입과 규준을 설정할 필요가 있다.

본 연구의 제한점과 이를 바탕으로 한 후속연구를 위한 제 언은 다음과 같다. 첫째, 본 연구는 서울특별시와 전라북도의 각 한 학교에 재학 중인 중학생을 연구대상으로 선정하였기 때문에 전체 중학생을 일반화하고 대표하기에는 한계가 있다 고 볼 수 있다. 따라서 후속 연구에서는 더욱 광범위한 지역을 통한 연구가 필요하다. 둘째, 본 연구에서는 척도 사용 과정에 서 일부 문항이나 요인을 삭제 후 분석이 이루어졌다. 이는 기 존 척도를 온전하게 사용하여 분석한 결과와 직접 비교하기에 는 어려움이 있다는 한계점이 있다. 셋째, 본 연구는 어머니의 감독과 심리적 통제를 중심으로 연구가 이루어졌다. 어머니 의 양육이 중요시되던 과거에 비해, 현재는 아버지의 양육 참 여가 점차 증가하고 있기 때문에 후속 연구에서는 어머니, 아 버지 각각의 영향을 살펴보는 것이 필요하다. 넷째, 본 연구에 서는 도덕적 이탈의 하위요인에서 책임분산의 요인부하량이 .40 이하로 산출되어 이를 제외한 후 분석하였다. 또한 '완곡 한 명명'과 ‘비난의 귀인’에 대한 내적 합치도도 다른 하위요인 과 비교하여 낮게 나타나 이를 제외하였다. 이는 Sohn과 Han (2019), H. S. Lee (2016)와 Yun (2018)의 연구결과와 비슷한 것 으로 나타난다. 따라서 후속 연구에서는 국내 도덕적 이탈 기 제 척도의 한계점을 보완하기 위해 타당화 작업의 필요성이 있다(Sohn \& Han, 2019).

이러한 제한점에도 본 연구는 다음과 같은 중요한 의의를 가진다. 첫째, 도덕적 이탈의 선행요인에 대한 연구는 아직 부 족한 실정으로, 본 연구는 도덕적 이탈의 선행요인에 대해 살 펴보았으며, 그 결과 어머니의 감독과 심리적 통제가 청소년 의 도덕적 이탈에 미치는 영향을 밝혔다는 데에 의의가 있다. 둘째, 청소년의 공격성을 살펴보기 위해 외적 요인인 어머니 의 감독, 심리적 통제와 내적, 인지적 요인인 청소년의 도덕적 이탈을 포함하여 공격성에 미치는 구조적 관계를 살펴보았다. 이 과정에서 어머니의 감독과 심리적 통제가 도덕적 이탈을 매개로 하여 공격성에 간접적 영향을 밝혔다는 것에 의의가 있다. 이와 같이 본 연구는 어머니의 감독, 심리적 통제 및 청 소년의 도덕적 이탈이 공격성에 중요한 영향을 미침을 확인할 수 있었으며, 이는 청소년 공격성 및 문제행동 예방을 위한 부 모 교육 프로그램이나 청소년 도덕성 향상 프로그램 개발 등 
에 필요한 기초자료를 제공할 수 있을 것으로 기대된다.

\section{Notes}

This article is a part of the first author's master's thesis submitted in 2019, and was presented as a poster at the 2019 Annual Autumn Conference of the Korean Association of Child Studies.

\section{Conflict of Interest}

No potential conflict of interest relevant to this article was reported.

\section{References}

\section{In English}

Albrecht, A. K., Galambos, N. L., \& Jansson, S. M. (2007). Adolescents' internalizing and aggressive behaviors and perceptions of parents' psychological control: A panel study examining direction of effects. Journal of Youth and Adolescence, 36, 673-684. doi:10.1007/s10964-007-9191-5

Bandura, A. (1991). Social cognitive theory of self-regulation. Organizational Behavior and Human Decision Processes, 50(2), 248-287. doi:10.1016/0749-5978(91)90022-L

Bandura, A., Barbaranelli, C., Caprara, G. V., \& Pastorelli, C. (1996). Mechanisms of moral disengagement in the exercise of moral agency. Journal of Personality and Social Psychology, 71(2), 364-374. doi:10.1037/0022-3514.71.2.364

Barber, B. K. (1996). Parental psychological control: Revisiting a neglected construct. Child Development, 67(6), 3296-3319. doi:10.1111/j.1467-8624.1996.tb01915.x

Barber, B. K., \& Harmon, E. L. (2002). Violating the self: Parental psychological control of children and adolescents. In B. K. Barber (Ed.), Intrusive parenting: How psychological control affects children and adolescents (pp. 15-52). Washington, DC: American Psychological Association.

Blitstein, J. L., Murray, D. M., Lytle, L. A., Birnbaum, A. S., \& Perry, C. L. (2005). Predictors of violent behavior in an early adolescent cohort: Similarities and differences across genders. Health Education and Behavior, 32(2), 175-194. doi:10.1177/1090198104269516

Campaert, K., Nocentini, A., \& Menesini, E. (2018). The role of poor parenting and parental approval for children's moral disengagement. Journal of Child and Family Studies, 27, 2656-2667. doi:10.1007/s10826-018-1097-1

Ceballo, R., Ramirez, C., Murray, K. H., \& Maltese, K. L. (2003). Community violence and children's psychological well-being : Does parental monitoring matter? Journal of Clinical Child and Adolescent Psychology, 32(4), 586-592. doi:10.1207/ S153744424JCCP3204_11

Crick, N. R., \& Grotpeter, J. K. (1995). Relational aggression, gender, and social-psychological adjustment. Child Development, 66(3), 710-722. doi:10.1111/j.1467-8624.1995.tb00900.x

Davies, P. T., \& Cummings, E. M. (1994). Marital conflict and child adjustment: An emotional security hypothesis. Psychological Bulletin, 116(3), 387-411. doi:10.1037/00332909.116.3.387

Fuligni, A. J., \& Eccles, J. S. (1993). Perceived parent-child relationships and early adolescent' orientation toward peers. Developmental Psychology, 29(4), 622-632. doi:10.1037/00121649.29.4.622

Guerra, N. G., \& Slaby, R. G. (1990). Cognitive mediators of aggression in adolescent offenders: II. intervention. Developmental Psychology, 26(2), 269-277. doi:10.1037/00121649.26.2.269

Harter, S. (1988). Developmental processes in the construction of the self. In T. D. Yawkey \& J. E. Johnson (Eds.), Integrative processes and socialization: Early to middle childhood (pp. 4578). Hillside, NJ: Pennsylvania State University.

Hu, L., \& Bentler, P. M. (1999). Cutoff criteria for fit indexes in covariance structure analysis: Conventional criteria versus new alternatives. Structural Equation Modeling: A Multidisciplinary Journal, 6(1), 1-55. doi:10.1080/10705519909540118

Kline, R. B. (2015). Principles and practice of structural equation modeling (4th ed.). New York: Guilford publications.

Kokkinos, C. M., Voulgaridou, I., Mandrali, M., \& Parousidou, C. (2016). Interactive links between relational aggression, theory of mind, and moral disengagement among early adolescents. Psychology In The Schools, 53(3), 253-269. doi:10.1002/pits.21902

Little, T. D., Cunningham, W. A., Shahar, G., \& Widaman, K. F. (2002). To parcel or not to parcel: Exploring the question, weighing the merits. Structural Equation Modeling: A Multidisciplinary Journal, 9(2), 151-173. doi:10.1207/ S15328007SEM0902_1

Little, T. D., Rhemtulla, M., Gibson, K., \& Schoemann, A. M. (2013). Why the items versus parcels controversy needn't be one. Psychological Methods, 18(3), 285-300. doi:10.1037/ a0033266

Loukas, A., Paulos, S. K., \& Robinson, S. (2005). Early adolescent social and overt aggression: Examining the roles of social anxiety and maternal psychological control. Journal of Youth and Adolescence, 34, 335-345. doi:10.1007/s10964-005- 
5757-2

Malti, T., \& Krettenauer, T. (2013). The relation of moral emotion attributions to prosocial and antisocial behavior: A metaanalysis. Child Development, 84(2), 397-412. doi:10.1111/ j.1467-8624.2012.01851.x

Menesini, E., Sanchez, V., Fonzi, A,. Ortega, R., Costabile, A., \& Feudo, G. L. (2003). Moral emotions and bullying: A cross-national comparison of differences between bullies, victims and outsiders. Aggressive Behavior, 29(6), 515-530. doi:10.1002/ab. 10060

Pelton, J., Gound, M., Forehand, R., \& Brody, G. (2004). The moral disengagement scale: Extension with an american minority sample. Journal of Psychopathology and Behavioral Assessment, 26, 31-39. doi:10.1023/B:JOBA.0000007454.34707.a5

Pettit, G. S., Laird, R. D., Dodge, K. A., Bates, J. E., \& Criss, M. M. (2001). Antecedents and behavior-problem outcomes of parental monitoring and psychological control in early adolescence. Child Development, 72(2), 583-598. doi:10.1111/1467-8624.00298

Rathert, J., Fite, P. J., Gaertner, A. E., \& Vitulano, M. (2011). Erratum to: Associations between effortful control, psychological control and proactive and reactive aggression. Child Psychiatry and Human Development, 42, 741. doi:10.1007/s10578-011-0262-1

Röonnlund, M., \& Karlsson, E. (2006). The relation between dimensions of attachment and internalizing or externalizing problems during adolescence. The Journal of Genetic Psychology, 167(1), 47-63. doi:10.3200/GNTP.167.1.47-63

Stattin, H., \& Kerr, M. (2000). Parental monitoring: A reinterpretation. Child Development. 71(4), 1072-1085. doi: $10.1111 / 1467-8624.00210$

Steinberg, L. (1990). Interdependence in the family: Autonomy, conflict, and harmony in the parent-adolescent relationship. In S. S. Feldman \& G. R. Elliott (Eds.), At the threshold: The developing adolescent (pp. 255-276). Cambridge, MA: Harvard University Press.

Steinberg, L., Fletcher, A. C., \& Darling, N. (1995). Parental monitoring and peer influences on adolescent substance use. In J. McCord (Ed.), Coercion and punishment in long-term perspectives (pp. 259-271). Cambridge, GB: Cambridge University Press. doi:10.1017/CBO9780511527906.016

Vaillancourt, T., Brendgen, M., Boivin, M., \& Tremblay, R. E. (2003). A longitudinal confirmatory factor analysis of indirect and physical aggression: Evidence of two factors over time? Child Development, 74(6), 1628-1638. doi:10.1046/j.1467-8624.2003.00628.x

\section{In Korean}

Cha, E. J., \& Kim, K. H. (2016). The influence of parental child- rearing attitudes on adolescents' mobile phone dependence: Testing the mediating effect of aggression. Social Welfare Policy, 43(4), 51-78.

Chang, Y. O. (2015). The effects of parental behaviors on adolescent overt aggression and depression. Korean Journal of Youth Studies, 22(2), 199-221.

Cho, I.-H. (2012). The relationship between intrusive child-rearing attitude of the parents and morality of students as perceived by male high-school students. The Educational Research for Tomorrow, 25(1), 95-130.

Han, Y. K. (2008). The relation of psychological variables to relational aggression in early adolescence (Master's thesis). Retrieved from http://www.riss.kr/link?id=T11390100

Hong, S. (2000). The criteria for selecting appropriate fit indices in structural equation modeling and their rationales. Korean Journal of Clinical Psychology, 19(1), 161-177.

Jeon, S.-Y. (2007). The effect of mother's psychological control, children's behavioral autonomy an self control on children's problems behavior. Journal of Korean Management Association, 25(4), 169-179.

Kim, G. (2010). AMOS 18.0 gujobangjeongsik mohyeong bunseok [AMOS 18.0 구조방정식 모형 분석]. Seoul: Hannarae Academy.

Kim, H. (2014). The effect of parental psychological control on attributional style and aggression (Master's thesis). Retrieved from http://www.riss.kr/link?id=T13414535

Kim, H. H. (2003). The effect of maternal monitoring and psychological control on problem behavior and internet delinquency in adolescence. Korean Journal of Youth Studies, 10(3), 133-153.

Kim, H. Y. (2010). Maternal control and children's emotional regulation as related to child's aggression (Master's thesis). Retrieved from http://www.riss.kr/link?id=T11926800

Kim, J. M., \& Kim, J. M. (2013). The effect of parental psychological control and moral disengagement on children's participant role behavior in a bullying situations. Korean Journal of Child Studies, 34(6), 13-29. doi:10.5723/ KJCS.2013.34.6.13

Kim, K. A., \& Kweon, H. S. (2015). The relations between parental psychological control and relational aggression: Mediating effects of social evaluative anxiety and anger-in. The Korea Journal of Youth Counseling, 23(1), 139-156.

Kim, S. (2007). The effects of parenting behavior for predicting physical and psychological aggression among childrenFocused on mediating effects of emotion regulation-. Korean Journal of Social Welfare Studies, 32, 65-95.

Ko, J. J. (2005). The effect of parental monitoring and adolescents' self-control on adolescents' problem behavior. International Journal of Human Ecology, 43(2), 1-17.

Lee, D., \& Yum, S. (2015). Multiple mediated effects of ego- 
resiliency and depression in the relation between the affectionate parenting attitude and aggression. The Korea Journal of Youth Counseling, 23(2), 277-298.

Lee, E., \& Lea, E. (2012). The effects of perceived parenting attitude on problem behavior of adolescence: Focused on mediating effect of a guilty. The Korea Journal of Youth Counseling, 20(1), 55-70.

Lee, E. G., \& Han, S.-Y. (2016). Effects of affection, monitoring and inconsistent parenting on the emotional problems of children and adolescents. The Korean Journal of Human Development, 23(3), 153-172. doi:10.15284/kjhd.2016.23.3.153

Lee, H., \& Park, J. H. (2014). The effects of parental psychological control and cognitive emotion regulation on relational aggression amongst middle school students. Studies on Korean Youth, 25(3), 233-258.

Lee, H., \& Kim, H. (2011). Gender differences on the characteristics and affecting factors of peer relation problems among adolescents. The Korean Journal of Woman Psychology, 16(1), 43-68.

Lee, H. S. (2016). Influence of parental psychological control on adolescents' internalizing and externalizing problematic behaviors: The moderating effect of moral disengagement (Master's thesis). Retrieved from http://www.riss.kr/ link?id=T14185212

Lee, J. S. (2016). The effects of mothers' parenting attitudes on young teenagers' school violence perpetration: Mediator effect of morality. Journal of School Social Work, 36, 73-95.

Min, J.-I., \& Han, S.-Y. (2012). The effects of mother's psychological and behavioral control on young children's problem behaviors. The Korean Journal of Human Development, 19(4), 117-137.

Ministry of Education. (2018). 2018nyeon 1cha haggyopoglyeog siltaejosa gyeolgwa [2018년 1차 학교폭력 실태조사 결과]. Retrieved from MOE website: http://www.moe.go.kr.

Noh, S.-A. (2012). The mediating effects of children's emotional regulation on the relationships between mother's psychological control and children's aggression (Master's thesis). Retrieved from http://www.riss.kr./link?id=T12659419

Oh, Y. J. (2010). Predictors of developmental trajectory change and clustering related to adolescents' internalizing or externalizing problem behaviors (Doctoral dissertation). Retrieved from http://www.riss.kr/link?id=T11927988

Park, J. K. (2001). The relations of the maternal monitoring and information sources of parental knowledge to externalizing and internalizing behaviors of adolescents (Master's thesis). Retrieved from http://www.riss.kr/link?id=T8952307

Seo, M. J., \& Kim, K. Y. (2006). Analysis of variables for classifying types of outsiders in bullying situations. Korean Journal of Child Studies, 27(6), 35-51.

Seo, S. (2018). The relationship between beliefs in a just world and aggression: the moderating effect of normative beliefs about aggression and moral disengagement (Master's thesis). Retrieved from http://www.riss.kr/link?id=T14886182

Shin, H., \& Kim, S. (2014). Differences in attitudes toward bullying and moral disengagement among aggression clusters in middle school students. Korean Journal of Youth Studies, 21(3), 307-331.

Sohn, E.-H., \& Han, S.-Y. (2019). Effects of mothers perfectionism on their adolescent daughters' moral disengagement through mothers psychological control. Korean Journal of Child Studies, 40(2), 131-142. doi:10.5723/kjcs.2019.40.2.131

Yim, H., Kim, S., \& Chung, I. (2014). The differential effects of positive parenting attitudes on adolescents' psychsocial adjustment. Journal of Adolescent Welfare, 16(4), 1-27.

Yoo, K. (2018). The relationship between adolescent's narcissism and relational aggression: The mediating effects of rejection sensitivity and moral disengagement (Master's thesis). Retrieved from http://www.riss.kr/link?id=T14692549

Yun, N. (2018). The effects of paternal and maternal parenting behaviors on adolescents' delinquency: The mediating role of moral disengagement (Master's thesis). Retrieved from http://www.riss.kr/link?id=T14717887

\section{ORCID}

Hye yun Park http://orcid.org/0000-0002-8550-785X

Sae-Young Han http://orcid.org/0000-0001-8207-5927

Received February 29, 2020

Revision received April 24, 2020

Accepted May 31, 2020 